\title{
Peran Serta Elit Desa dalam Pengembangan Pariwisata di Desa Cempaga Kecamatan Banjar Kabupaten Buleleng Bali
}

\author{
Nanda Diah Andini', I.B. Gde Pujaastawa ${ }^{2}$ \\ ${ }^{12}$ Prodi Antropologi Fakultas Ilmu Budaya Unud \\ ${ }^{1}$ [nandadini95@gmail.com], ${ }^{2}$ [ibg_pujaastawa@yahoo.co.id] \\ *Corresponding Author
}

\begin{abstract}
Abstrak
Tourism sector has become driving force in development of Bali area. Even today, tourism is inseparable part of community and development at Bali area. Cempaga Buleleng village because of elite (leaders of community) initiative is doing tourism development. Tourism development in Cempaga village has give an impact of social cultural, economic, and environment. As for this study aims to know of (a) form of participation elite in tourism development at Cempaga village, (b) impact from tourism development at Cempaga village. Participation elite in tourism development at Cempaga village can be review using a theory from Karl Mannheim, and review about impact of tourism development is using a theory from Dickman. Concept used in this study is about participation, elite, and tourism development. This study used ethnograpic research methods with qualitative research and collecting data from determination of informants, observation, interview, and literature review. The results form of participation elite in tourism development at Cempaga village seen in some activities as like; be allied and collaborate developing tourism with Forum Panca Desa Mahagotra Bali Aga $S C T P B$, participation at preservation and development of art and culture Cempaga village. Tourism development at Cempaga village involve of positive impact from social cultural are seen in improvement of tourism management. The negative impact from tourism development is traditional art that seen as a commercial resource to attract tourists. The positive impact from the economic perspective are seen in the increase of people's income but also has a negative impact on increasing only at certain moments or seasonally. Positive impacts on the environment are seen in maintaining environmental hygiene by making landfills (TPST). While the negative impact for the environment is from construction of many stalls and house estates.Suggestions from the results of this study on the government is expected to provide adequate facilities and budget for clean water to build facilities and infrastructure supporting tourism, to the tourism industry is expected in the development of tourism at Cempaga village oriented to all levels of society to make income distribution, and to the public are advised to increase active role in the field of tourism so as to improve the welfare.
\end{abstract}

Keywords : participation, elite, tourism development.

\section{Latar Belakang}

Keunikan dan keragaman budaya, serta didukung oleh keindahan alam yang dimiliki, menjadikan Bali terkenal sebagai salah satu daerah tujuan wisata di Indonesia. Sektor kepariwisataan telah menjadi motor penggerak dalam pembangunan di daerah Bali. Bahkan, dewasa ini kepariwisataan merupakan bagian yang tak terpisahkan dari masyarakat dan pembangunan daerah Bali.

Pembangunan pariwisata Bali ditujukan untuk mengembangkan dan mendayagunakan berbagai potensi pariwisata daerah dan meningkatkan peran serta masyarakat. Pembangunan pariwisata Bali memiliki tujuan untuk meningkatkan kualitas kehidupan masyarakat yang meliputi kehidupan 
sosial, budaya, ekonomi dan kelestarian lingkungan. Untuk itu, pembangunan pariwisata Bali diarahkan agar mampu menjadi penghasil devisa, mendorong pertumbuhan ekonomi masyarakat, meningkatan pendapatan daerah, memberdayakan perekonomian masyarakat, memperluas lapangan kerja dan kesempatan berusaha, serta meningkatan pengenalan dan pemasaran produk daerah dan nasional dalam rangka meningkatkan kesejahteraan rakyat dengan tetap memelihara nilai-nilai agama dan kelestarian lingkungan (Biro Humas \& Protokol Setwilda Tingkat I, 1998: 17).

Desa Sidetapa, Cempaga, Tigawasa, Pedawa, dan Banyuseri merupakan desa di Bali yang berada dalam satu kawasan yang saling berdekatan dengan satu kecamatan yang sama yaitu Kecamatan Banjar Kabupaten Buleleng. Kondisi geografis desa yang berada di pegunungan menyebabkan akses untuk menuju desa-desa tersebut masih susah dan menyebabkan perkembangan pembangunan pun berlangsung lambat. Untuk mempercepat pembangunan desa dan sebagai motor penggerak dalam pembangunan maka akan lebih menguntungkan dengan mengedepankan sektor pariwisata.

Melihat akses dan potensi dari Desa Sidetapa, Cempaga, Tigawasa, Pedawa, dan Banyuseri yang berbedabeda, akan sulit jika mereka mengembangkan kepariwisataan desa dengan berdiri secara independen. Oleh karena itu, atas inisiatif elit (tokoh dan pemimpin masyarakat) dari masingmasing desa untuk dikembangkannya kepariwisataan desa dengan "Paket Perjalanan Wisata Terintegrasi yang dilakukan dengan cara menyatukan program-program pengembangan wisata Desa Sidatapa, Cempaga, Tigawasa, Pedawa, dan Banyuseri yang memiliki citra dalam pariwisata karena keunikan potensi desa yang dimiliki berbeda dengan daerah lain.

Desa Cempaga merupakan desa yang tergabung dalam "Paket Perjalanan Wisata Terintegrasi” ini. Desa Cempaga memiliki potensi untuk pengembangan pariwisata yang lebih banyak dibanding desa lainnya dalam program ini. Pengembangan pariwisata di Desa Cempaga tidak terlepas dari pengawasan dan pengelolaan elit Desa Cempaga yang merupakan pelopor dan penggerak dari "Paket Perjalanan Wisata Terintegrasi" desa ini. Pengembangan pariwisata yang dilakukan elit Desa Cempaga akan memberikan beberapa dampak positif maupun negatif terhadap Desa Cempaga baik dari aspek ekonomi, sosial budaya dan lingkungan. Terkait persoalan tersebut, maka permasalahan dalam kajian ini akan lebih difokuskan pada peran serta elit desa dan dampak dari pengembangan pariwisata yang dilakukan elit desa di Desa Cempaga.

\section{Pokok Permasalahan}

Permasalahan dalam kajian ini akan dijelaskan dengan menjawab pertanyaan penelitian yang diformulasikan sebagai berikut :

a. Bagaimana bentuk peran serta elit desa dalam pengembangan pariwisata di Desa Cempaga?

b. Bagaimana dampak pengembangan pariwisata di Desa Cempaga?

\section{Tujuan Penelitian}

Berdasarkan latar belakang dan rumusan masalah di atas, maka dapat dikemukakan tujuan penelitian ini adalah sebagai berikut :

1) Untuk mengetahui bentuk peran serta elit desa dalam pengembangan pariwisata di Desa Cempaga. 2) Untuk mengetahui dampak pengembangan pariwisata di Desa Cempaga. 


\section{Metode Penelitian}

Penelitian ini menggunakan metode penelitian etnografi yang termasuk ke dalam penelitian kualitatif dengan sumber data yang digunakan yaitu sumber data primer dan data sekunder serta menggunakan teknik pengumpulan data melalui penentuan informan, observasi, wawancara, serta studi kepustakaan dan dokumentasi. Kemudian dideskripsikan, dibandingkan, dan diinterpretasikan secara kualitatif. Tahapan lengkapnya yaitu mulai dari pengumpulan data, pengorganisasian data, pengeditan data, dan penganalisisan data sesuai dengan permasalahan. Dengan demikian diperoleh kesimpulan yang dijadikan bahan dalam pembahasan penelitian.

\section{Hasil dan Pembahasan}

\subsection{Pengembangan Pariwisata di Desa Cempaga}

Pengaruh Hindu di Bali tidak terjadi dalam kurun waktu tertentu dan tidak memberikan pengaruh secara merata pada masyarakat Bali yang mengakibatkan munculnya klasifikasi masyarakat berdasarkan kuat lemahnya pengaruh Hindu yang diterima. Menurut Utama (2015:1) perbedaan pengaruh dari kebudayaan Jawa Hindu di berbagai daerah di Bali dalam zaman Majapahit, menyebabkan adanya dua bentuk masyarakat di Bali: masyarakat Bali Aga (wong Bali Aga) dan Bali Majapahit (wong Majapahit).

Masyarakat Bali Aga sedikit sekali mendapat pengaruh kebudayaan Jawa Hindu dari Majapahit sehingga memiliki struktur tersendiri. Orang-orang Bali Aga yang tidak mau tunduk kepada kekuasaan Majapahit di Bali pada umumnya mendiami desa-desa di daerah pegunungan seperti Sembiran, Sidatapa, Cempaga, Tigawasa, Pedawa, Banyuseri di Kabupaten Buleleng dan Tenganan Pegringsingan di Kabupaten Karangasem
(Bagus, 2004:286). Desa Sidetapa, Cempaga, Tigawasa, Pedawa, dan Banyuseri merupakan Desa Bali Aga yang berada dalam satu kawasan yang saling berdekatan dan dalam satu kecamatan yang sama yaitu Kecamatan Banjar Kabupaten Buleleng yang saat ini sedang mengembangkan sektor kepariwisataan mereka dengan program "Paket Perjalanan Wisata Terintegrasi".

Program ini sudah direncanakan sejak tahun 2015 namun baru dapat terlaksana pada tahun 2016 dengan dilantiknya "Panca Desa Mahagotra Bali Aga SCTPB" untuk mengembangkan potensi desa terintegrasi dan menjaga keamanan desa. Daerah yang terintegrasikan ini berada dalam satu zona yang diharapkan saling mendukung serta dapat membuat perencanaan secara bersama dalam pengelolaan pengembangan wisata yang ada, sehingga meningkatkan pendapatan desa-desa yang tergabung dalam paket perjalanan wisata terintegrasi dengan citra sebagai desa Bali Aga yang ada di Kecamatan Banjar Kabupaten Buleleng.

Desa Cempaga yang termasuk salah satu desa dalam "Paket Perjalanan Wisata Terintegrasi" ini, merupakan desa yang paling banyak memiliki potensi untuk pengembangan pariwisata dibandingkan desa-desa lainnya. Pengembangan pariwisata di Desa Cempaga tidak terlepas dari pengembangan pariwisata Bali yaitu pariwisata budaya. Pengembangan pariwisata di Desa Cempaga dikelola oleh suatu forum yang disebut Panca Desa Mahagotra Bali Aga SCTPB (Sidatapa, Cempaga, Tigawasa, Pedawa, Banyuseri).

Forum Panca Desa Mahagotra Bali Aga SCTPB merupakan sarana komunikasi dari masing-masing desa dalam membahas, mengatur, dan mengembangkan pariwisata yang ada di desa-desa Bali Aga SCTPB. Dalam forum ini terdapat pengurus yang mengatur pengembangan pariwisata di 
desa Bali Aga yang terdiri dari para kepala desa, tokoh masyarakat, staff desa, dan juga masyarakat dari masingmasing desa SCTPB. Susunan pengurus diatas dibagi menjadi 4 bagian, terdiri dari pengurus inti, pengurus baga parhyangan, baga pawongan, dan baga palemahan. Sesuai dengan konsep tri hita karana pengurus pariwisata di desa Bali Aga dibagi dengan fungsinya masing-masing.

Desa Cempaga selain ikut tergabung dalam Forum Panca Desa Mahagotra Bali Aga SCTPB juga memiliki suatu badan yang mengatur mengenai pariwisata di Desa Cempaga dengan sebutan Badan Wisata Desa Cempaga (Pokdarwis Desa Cempaga). Pokdarwis Desa Cempaga memiliki visi dan misi dalam mengembangkan pariwisata yang ada di Desa Cempaga mencakup mengenai pengembangan daya tarik wisata dimana Inskeep membagi daya tarik wisata ke dalam tiga kategori, yaitu (1) daya tarik wisata budaya yang berdasarkan kegiatan manusia mengenai adat istiadat kehidupan keseharian masyarakat yang khas; (2) daya tarik wisata alam yang berdasarkan pada keadaan dan keunikan lingkungan alam; dan (3) daya tarik wisata khusus seperti area pembelanjaan ataupun kawasan rekreasi.

\subsection{Pelestarian dan Pengembangan Seni - Budaya Desa Cempaga}

Seni budaya merupakan bagian internal dari kebudayaan Bali. Pengembangan pariwisata perlu di sesuaikan dengan kondisi masyarakat setempat. Pariwisata yang sedang dikembangkan di Desa Cempaga dan desa Bali Aga SCTPB adalah pariwisata yang berbasiskan budaya. Sebagai desa Bali Aga yang memiliki sistem dan budaya yang berbeda dengan desa-desa lainnya yang ada di Bali membuat pengembangan pariwisata budaya di desa Bali Aga SCTPB lebih unggul.
Keunggulan potensi pariwisata budaya yang ada di desa Bali Aga SCTPB merupakan implementasi dari program kerja elit desa dalam pembangunan selama periode 2015 - 2020. Kegiatan pengembangan pariwisata di Desa Cempaga berorientasi ke dalam dan juga keluar. Program yang diorientasikan kedalam adalah untuk memperbesar pendapatan anggaran desa dan pendapatan masyarakat desa. Sedangkan pengembangan pariwisata yang berorientasi keluar adalah untuk memperkenalkan dan melestarikan seni budaya yang ada di Desa Cempaga.

Seni budaya seperti kesenian adalah salah satu fokus dalam kebudayaan Bali. Kesenian pada masyarakat Bali merupakan suatu unsur yang nampak amat digemari oleh warga masyarakatnya, sehingga terlihat lebih mendominasi dalam kehidupan masyarakat Bali. Pengembangan pariwisata yang berdasarkan budaya tidak terlepas dari kesenian, adat istiadat dan ajaran agama hindu. Bentuk-bentuk kegiatan yang dikembangkan elit desa yang berhubungan dengan kesenian, adat istiadat, dan ajaran agama hindu merupakan upaya menggali potensi wisata yang ada di Desa Cempaga.

Desa Cempaga memiliki berbagai seni budaya yang tumbuh dan berkembang dalam masyarakat. Peran serta elit desa dalam pelestarian dan pengembangan seni budaya Desa Cempaga terlihat dari beberapa kegiatan perencanaan dan pengembangan pariwisata seperti (1) membuat kalender kegiatan seni budaya Desa Cempaga, (2) membuat perencanaan pembangunan miniatur rumah adat tradisional khas Bali Aga Desa Cempaga, (3) pencarian peninggalan bersejarah yang berupa sarkofagus, jenis sanggah dan prasasti, (4) mempromosikan tradisi-tradisi upacara sakral yang unik di Desa Cempaga seperti upacara ngusabha 
kuningan, nyepi desa, upacara ngaben, upacara tiga bulanan bayi, ataupun perkawinan, serta (5) mengembangkan seni bela diri pencak silat khas Bali Aga Desa Cempaga.

Pengembangan pariwisata di Desa Cempaga tidak terlepas dari peran serta elit desa dalam setiap rencananya. Seperti yang diungkapkan oleh Mannheim dalam teorinya mengenai elit bahwa peran serta elit dalam sebuah masyarakat tidak dapat dihilangkan. Sebagai tokoh yang berpengaruh, elit dapat mendorong massa menuju kepada arah untuk mewujudkan kepentingannya. Baik kepentingan organisasi ataupun kepentingan pribadi. Dalam hal ini, elit Desa Cempaga memiliki pengaruh melakukan rencana pengembangan pariwisata untuk mendorong massa menuju ke arah kepentinggan organisasi dan juga pribadi dari masing-masing elit untuk mendapatkan keuntungan bersama.

\subsection{Pengembangan Pariwisata dari segi Ekonomi Masyarakat Desa Cempaga}

Pembangunan pariwisata pada suatu daerah mampu meningkatkan penerimaan devisa, peningkatan kesempatan kerja dan peluang usaha, peningkatan pendapatan pemerintah dari pajak dan keuntungan badan usaha milik pemerintah, dan sebagainya. Pariwisata diharapkan mampu menghasilkan angka pengganda (multiplier effect) yang tinggi, melebihi angka pengganda pada berbagai kegiatan ekonomi lainnya. Peranan pariwisata dalam pembangunan ekonomi bagi daya tarik wisata seperti Bali, yang memang sudah terkenal sebagai salah satu daerah tujuan wisata dunia, tidak perlu dipertanyakan lagi. Sistem pariwisata yang berhubungan dengan sektor ekonomi terdapat banyak aktor yang berperan dalam menggerakan sistem. Aktor tersebut adalah insan-insan pariwisata yang ada pada berbagai sektor.
Secara umum insan pariwisata dikelompokkan menjadi tiga pilar utama, yaitu (1) masyarakat, (2) swasta, dan (3) pemerintah.

Peran serta elit Desa Cempaga dalam pengembangan pariwisata di Desa Cempaga yang berasaskan pariwisata budaya serta berorientasi pada masyarakat dan dikelola oleh masyarakat secara langsung membuat beberapa bentuk kegiatan untuk meningkatkan taraf ekonomi masyarakat seperti, (1) budidaya pembuatan gula aren untuk tujuan wisata agriculture, (2) mengembangkan usaha sarana prasarana pariwisata berupa restaurant, home stay, spa/massage, laundry, dan transportasi di desa Cempaga, serta (3) pengembangan wisata kerajinan untuk dipromosikan yang berupa kerajinan bambu, kerajinan perak, dan kerajinan ukir/ patung.

Peran serta elit desa dalam mengembangkan program pariwisata dilakukan dengan bekerjasama serta saling menguntungkan untuk masyarakat ataupun elit desa itu sendiri sebagai katalisator. Hal ini agar semua pihak dapat ikut berperan serta dalam mengembangkan pariwisata yang ada di Desa Cempaga dan diharapkan juga bisa meningkatkan taraf ekonomi masyarakat Desa Cempaga melalui sektor pariwisata.

\subsection{Penataan Lingkungan Daya Tarik Wisata Desa Cempaga}

Industri pariwisata umumnya didasarkan atas ketersediaan sumberdaya alam seperti udara, daratan dan air. Sumberdaya alam tersebut dijadikan obyek sekaligus produk bagi industri pariwisata. Obyek pengembangan pariwisata bertumpu pada lingkungan serta ekosistem. Salah satu karakter dari pariwisata adalah pariwisata sangat tergantung pada lingkungan asli dan alami.

Peran serta elit desa dalam penataan lingkungan daya tarik wisata Desa 
Cempaga terlihat dengan kegiatankegiatan seperti, (1) mengelola Desa Cempaga menjadi kawasan wisata yang bersih tanpa sampah, (2) mengelola sampah organik menjadi pupuk organik cair dengan bioaktivator buatan sendiri menggunakan tabung besar, (3) membuat TPST (Tempat Pembuangan Sampah Terpadu) untuk menangani masalah sampah anorganik di Desa Cempaga, (4) membuat Perdes No. 6 tahun 2016 mengenai kebersihan lingkungan, (5) membuat badan pengelola bank sampah di Desa Cempaga, (6) penanaman pohon di semua areal desa, termasuk penanaman pohon buah di hutan desa untuk menjaga ekosistem satwa didalamnya, serta (7) memasang pemberitahuan larangan pemburuan satwa dalam hutan.

Peran serta elit desa dalam penataan lingkungan daya tarik wisata dimulai dengan mengajak dan menyadarkan masyarakat desa mengenai bagaimana pentingnya lingkungan yang kemudian membuat kebijakan-kebijakan mengenai penataan lingkungan sehingga lingkungan yang baik untuk pariwisata akan tetap terjaga. Dengan penataan daya tarik wisata yang mengindahkan lingkungan akan mendatangkan keuntungan baik untuk masyarakat sendiri ataupun untuk wisatawan yang hadir. Sebagaimana yang diungkapkan oleh Yoeti (1997:189), bahwa penataan daya tarik wisata dengan memperhatikan lingkungan akan menjamin kelestarian lingkungan dan kualitas lingkungan akan terjaga dengan baik serta akan berdampak positif bagi kehidupan sosial masyarakatnya.

\subsection{Dampak Sosial Budaya}

Pariwisata budaya sebagai suatu kebijakan pengembangan kepariwisataan menekankan pada penampilan unsurunsur budaya sebagai aset utama untuk menarik para wisatawan berkunjung. Pelestarian seni dan budaya dalam misi pariwisata budaya diarahkan pada penciptaan iklim untuk mendorong berkembangnya upaya masyarakat dengan cara menggali, berkreasi, dan memelihara bentuk-bentuk kesenian dan tradisi masyarakat. Elit dan masyarakat Desa Cempaga dalam mengembangkan pariwisata mencoba untuk menggali, berkreasi, dan memelihara bentuk-bentuk kesenian dan tradisi mereka.

Pengembangan pariwisata di Desa Cempaga dengan menggali, berkreasi, dan memelihara bentuk-bentuk kesenian dan tradisi mereka merupakan kegiatan yang berfokus pada kebudayaan. Kebudayaan yang dimaksud ialah keseluruhan pengetahuan yang dimiliki masyarakat mengenai apa yang mereka miliki dan rasakan yang dijadikan sebagai sistem penilaian terhadap sesuatu yang baik dan buruk. Suatu kebudayaan yang dianggap baik adalah sesuatu yang sesuai dengan ajaran dan harapan dari masyarakat itu, sedangkan yang dianggap buruk ialah sesuatu yang bertentangan dengan ajaran dan harapan dari suatu masyarakat (Yoeti, 2006:71).

Pengembangan pariwisata yang dilakukan oleh elit Desa Cempaga dalam berbagai bentuk kegiatan yang bertujuan untuk pelestarian seni dan budaya yang ada di Desa Cempaga merupakan sesuatu yang berorientasi pada kebudayaan masyarakat dan keuntungan bersama. Suatu kebijakan pengembangan pariwisata di Desa Cempaga yang dibuat sesuai dengan ajaran dan harapan masyarakat memberikan beberapa manfaat dan dampak positif seperti (1) meningkatnya minat masyarakat pelaku budaya untuk bekerja dalam bidang pariwisata, (2) peningkatan manajemen pengelolaan seni dan budaya yang ada di Desa Cempaga, (3) meningkatnya kualitas cipta seni dan budaya yang menunjang pariwisata, (4) terjadinya perubahan perilaku dalam hal etiket yang lebih baik dan cara berkomunikasi yang 
baik kepada wisatawan ataupun pendatang, serta (5) menghilangkan prasangka-prasangka buruk terhadap etnis lain.

Budaya pariwisata merupakan budaya mondial dengan dominasi budaya Barat. Salah satu ciri dari budaya Barat ini adalah kuatnya daya centripetal yang melakukan penetrasi, merasuki semua budaya masyarakat dunia lainnya. Penetrasi budaya ini pada akhirnya akan menyebabkan terjadinya homogenisasi, yaitu semakin miripnya ciri-ciri atau penampakan suatu daerah dengan daerah lainnya (Pitana \& Gayatri, 2005:125). Homogenisasi yang tidak sesuai dengan budaya tuan rumah dari suatu daerah tujuan wisata akan memberikan dampak negatif bagi masyarakat. Pengembangan pariwisata di Desa Cempaga yang memberikan dampak negatif terhadap sosial budaya terlihat pada (1) terjadinya pembedaan antara mereka yang mempunyai hubungan dengan pariwisata dan mereka yang tidak, (2) terjadinya erosi bahasa daerah, serta (3) kesenian tradisional dipandang sebagai sumberdaya komersial yang mengurangi kesakralannya.

\subsection{Dampak Ekonomi}

Pengembangan pariwisata di Desa Cempaga secara ekonomis memberikan beberapa dampak positif, seperti (1) peningkatan kesempatan kerja dan peluang usaha, (2) peningkatan pendapatan desa dari pajak pembangunan kawasan wisata, serta (3) peningkatan pendapatan masyarakat.

Menurut Nuryanti (1997: 18), berkembangnya industri pariwisata sebagai sektor andalan untuk meningkatkan devisa, memperluas dan meratakan kesempatan berusaha, lapangan kerja serta mendorong pembangunan daerah, ternyata telah mengundang berbagai perhatian dan kritik yang ditujukan pada berbagai dampak.

Dampak yang diharapkan (positif) dalam bidang ekonomi yang dirasakan oleh masyarakat akibat adanya pengembangan pariwisata di Desa Cempaga juga memberikan dampak yang tidak diharapkan (negatif) kepada masyarakat. Dampak yang tidak diharapkan (negatif) berupa (a) meningkatkan biaya pembangunan sarana dan prasarana, (b) meningkatkan harga barang-barang lokal dan bahan pokok, serta (c) peningkatan pendapatan yang sangat tinggi tetapi hanya musiman, sehingga pendapatan masyarakat tidak konstan.

\subsection{Dampak Lingkungan}

Pengembangan pariwisata dalam penataan lingkungan daya tarik wisata di Desa Cempaga memberikan beberapa dampak, baik dampak yang diharapkan (positif) ataupun tidak diharapkan (negatif). Dampak yang diharapkan (positif) dari pengembangan pariwisata terhadap lingkungan di Desa Cempaga terlihat pada terpeliharanya kebersihan lingkungan dengan dibuatnya TPST (Tempat Pembuangan Sampah Terpadu) untuk menangani masalah sampah di Desa Cempaga.

Dampak positif dari pengembangan pariwisata di Desa Cempaga selain terpeliharanya kebersihan lingkungan adalah terjaganya keistimewaan lingkungan, seperti hutan dan semua areal Desa Cempaga. Hal ini dikarenakan kegiatan penanaman pohon yang dilakukan di semua areal desa, termasuk penanaman pohon buah di hutan desa. Dengan adanya kegiatan penanaman pohon ini maka lingkungan alam di sekitar Desa Cempaga mendapatkan keistimewaan.

Pengembangan pariwisata selain memberikan dampak yang diharapkan (positif) juga memberikan dampak yang 
tidak diharapkan (negatif) terhadap lingkungan. Dampak ini dapat dilihat dengan mulai banyaknya pembangunan warung-warung dan alih lahan dari perkebunan menjadi perumahan. Polusi udara dan polusi estetika terjadi terutama ketika bangunan didirikan tanpa aturan penataan yang benar.

Dampak negatif pengembangan pariwisata juga terlihat pada lahan yang digunakan untuk membuat penginapan. Tanah di Desa Cempaga dimiliki oleh perorangan (masyarakat), tanah yang dimiliki desa hanyalah hutan dan jalur hijau yang tidak diperbolehkan untuk pembangunan. Oleh karena itu, investor langsung menyasar ke masyarakat apabila tertarik terhadap lahan yang akan digunakan untuk pembangunan.

Tanah milik perorangan (masyarakat) yang sudah di alih tangankan apabila menyalahi aturan pembangunan tidak bisa dilakukan tindakan dikarenakan belum ada peraturan yang mengatur fungsi lahan dan pembangunan baik dari desa dinas ataupun desa adat. Apabila hal ini dibiarkan akan mengakibatkan pembangunan yang tidak merata dan kepemilikan tanah yang lebih banyak orang luar daripada masyarakat asli Desa Cempaga.

\section{Simpulan}

\subsection{Kesimpulan}

Berdasarkan analisis terhadap permasalahan dalam kajian penelitian ini, dapat ditarik beberapa simpulan sebagai berikut.

a. Bentuk peran serta elit Desa Cempaga dalam pengembangan pariwisata di Desa Cempaga terlihat dalam berbagai kegiatan seperti; (1) bergabung dan bekerjasama mengembangkan pariwisata dalam Forum Panca Desa Mahagotra Bali Aga SCTPB, (2) berperan serta dalam pelestarian dan pengembangan seni budaya Desa
Cempaga dengan mempromosikan tradisi budaya unik khas Desa Cempaga serta mengembangkan seni bela diri pencak silat khas Desa Cempaga.

b. Dampak pengembangan pariwisata yang dilakukan elit Desa Cempaga meliputi dampak positif dan negatif terhadap sosial-budaya masyarakat, segi ekonomi masyarakat, serta lingkungan alam Desa Cempaga. Dampak positif terhadap sosialbudaya masyarakat terlihat pada peningkatan manajemen dan pengelolaan pariwisata yang diatur agar tetap ada pada tradisi dan sesuai dengan kebudayaan yang diajarkan turun temurun oleh para leluhur Desa Cempaga. Dampak negatif terhadap sosial-budaya masyarakat adalah kesenian tradisional yang dipandang sebagai sumberdaya komersial untuk menarik wisatawan. Dampak positif yang dilihat dari segi ekonomi terlihat pada peningkatan pendapatan masyarakat namun juga memberikan dampak negatif terkait peningkatan yang hanya pada saat-saat tertentu atau musiman. Dampak positif terhadap lingkungan terlihat pada terpeliharanya kebersihan lingkungan. Sedangkan dampak negatif terhadap lingkungan adalah dengan mulai banyaknya pembangunan warung-warung dan alih lahan dari perkebunan menjadi perumahan.

\subsection{Saran}

Berdasarkan penelitian ini ada beberapa saran yang perlu mendapat perhatian semua pihak yang terlibat dalam pengembangan pariwisata di Desa Cempaga yaitu sebagai berikut :

a. Kepada pemerintah diharapkan dapat memberikan fasilitas dan anggaran yang cukup untuk membangun sarana dan prasarana penunjang 
pariwisata khususnya akses air bersih baik untuk masyarakat ataupun wisatawan. Hal ini penting mengingat akses air bersih yang sulit di Desa Cempaga.

b. Kepada industri pariwisata diharapkan dalam pengembangan pariwisata Desa Cempaga tidak hanya berorientasi pada satu golongan tertentu saja tetapi semua lapisan masyarakat agar terjadi pemerataan pendapatan dan tidak ada kecemburuan sosial diantara masyarakatnya.

c. Kepada masyarakat disarankan agar meningkatkan peran aktif dalam bidang pariwisata. Hal ini penting mengingat banyaknya potensi untuk dikembangkannya pariwisata secara berkelanjutan sehingga dapat meningkatkan kesejahteraan masyarakat.

\section{Daftar Pustaka}

Bagus, I Gusti Ngurah. 2004. Manusia dan Kebudayaan Di Indonesia. Jakarta: Djambatan.

Biro Humas \& Protokol Setwilda Tingkat I.1998. Pariwisata Untuk Bali Konsep dan Implementasi Pariwisata Berwawasan Budaya. Denpasar.

Nuryanti, Wiend. (Ed) 1997. Tourism And Hiratage Managemen. Gadjah Mada University Pers.

Pitana, I Gde dan Gayatri, Putu G. 2005. Sosiologi Pariwisata. Yogyakata: ANDI.

Utama, I Wayan Budi. 2015. Wajah Bali Tanpa Kasta: Pudarnya Identitas Bali Aga. Denpasar : Kerjasama antara Program Pasca Sarjana
Universitas Hindu Indonesia dan Pustaka Ekspresi.

Yoeti, Oka A. Haji. 1997. Perencanaan dan Pengembangan Pariwisata. Jakarta: PT. Pradnya Paramitha.

Yoeti, dkk. 2006. Pariwisata Budaya. Jakarta: PT Balai Pustaka. 
